\title{
Kinosternon scorpioides albogulare (Duméril and Bocourt 1870) - White-Throated Mud Turtle, Swanka Turtle
}

\author{
German Forero-Medina ${ }^{1,2}$ and Olga V. Castaño-Mora ${ }^{2}$ \\ ${ }^{1}$ Nicholas School of the Environment, Duke University, \\ Durham, North Carolina 27708 USA [german.forero@duke.edu]; \\ ${ }^{2}$ Grupo de Biodiversidad y Conservación, Instituto de Ciencias Naturales, \\ Universidad Nacional de Colombia,Bogotá,Colombia [ovcastanom@unal.edu.co]
}

\begin{abstract}
Summary.- The White-throated Mud Turtle, Kinosternon scorpioides albogulare (Family Kinosternidae), is a poorly studied taxon that inhabits freshwater ponds, streams, and mangrove forests in Central America from Honduras to Panama and the Caribbean island of San Andrés, Colombia. Carapace length can reach approximately $150 \mathrm{~mm}$, but varies geographically, with some populations averaging only $125 \mathrm{~mm}$; clutch size ranges from 1-6, but usually $2-5$, and egg size is approximately $31 \times 15 \mathrm{~mm}$. Although little is known about its ecology, reproduction, and population trends, its occurrence in several countries, the fact that its habitat is included in some protected areas, the low human consumption, and the high estimated densities at some sites, support the premise that it is not currently globally threatened. However, there is a need for population and reproductive studies throughout its range in order to determine population trends and possible conservation recommendations in some areas. Local populations might be vulnerable to specific threats that must be evaluated independently. The population on San Andrés Island, Colombia, is potentially threatened by an introduced predator.

Distribution. - Colombia, Panama, Costa Rica, Nicaragua, Honduras, El Salvador. From western Honduras and EI Salvador to western Panama, including Nicaragua, Costa Rica, and the Colombian island of San Andrés in the Caribbean.

Synonymy. - Cinosternon albogulare Duméril and Bocourt 1870, Cinosternum albogulare, Kinosternon cruentatum albogulare, Kinosternon scorpioides albogulare.

STATuS. - IUCN 2011 Red List: Not Listed; CITES: Not Listed; Colombia: Red Book of Endangered Reptiles: Vulnerable (VU D2).
\end{abstract}

Taxonomy. - This subspecies of Kinosternon scorpioides was originally described as Cinosternon albogulare by Duméril and Bocourt (1870) from an individual collected in San José, Costa Rica, deposited in the Muséum d'Histoire Naturelle, Paris (Berry and Iverson 2001). Dunn and Saxe (1950) first used the combination Kinosternon scorpioides albogulare, referring to the San Andrés (Colombian island in the Caribbean) population and its similar type in Central America. There are three other subspecies currently recognized for K. scorpioides: K. s. scorpioides, K. s. abaxillare, and K. s. cruentatum (Cabrera and Colantonio 1997; Berry and Iverson 2001, 2011). According to Berry (1978), there

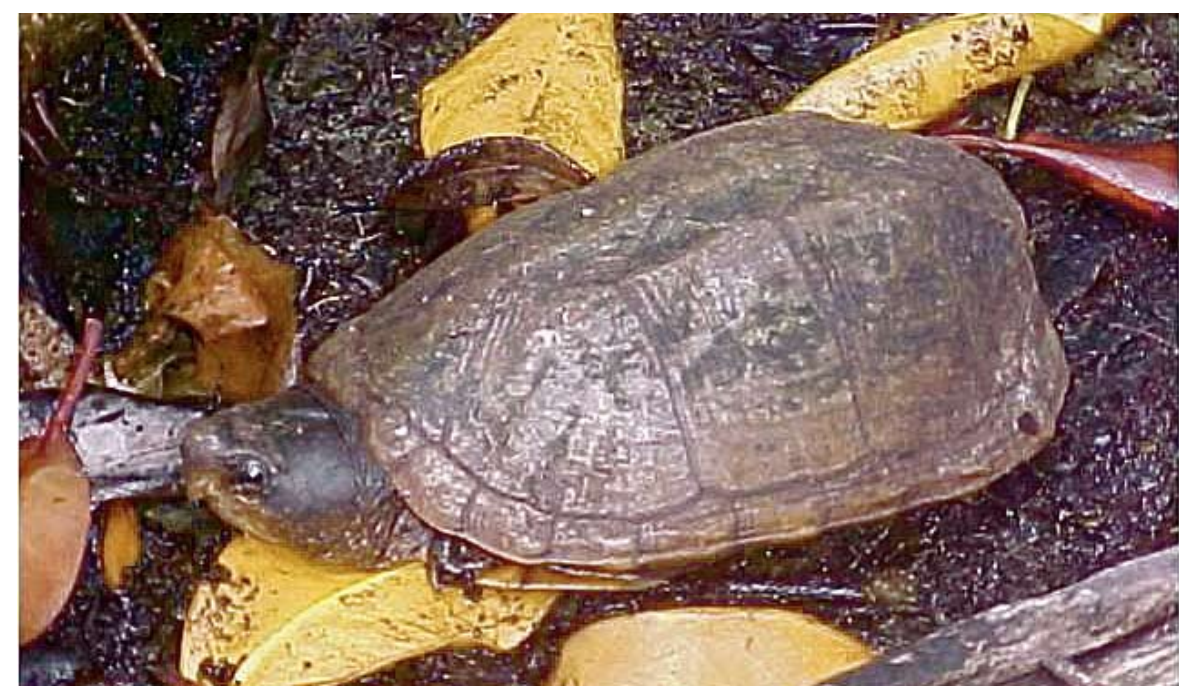

Figure 1. Adult Kinosternon scorpioides albogulare in a mangrove forest, San Andrés Island, Colombia. Photo by G. Forero-Medina. 


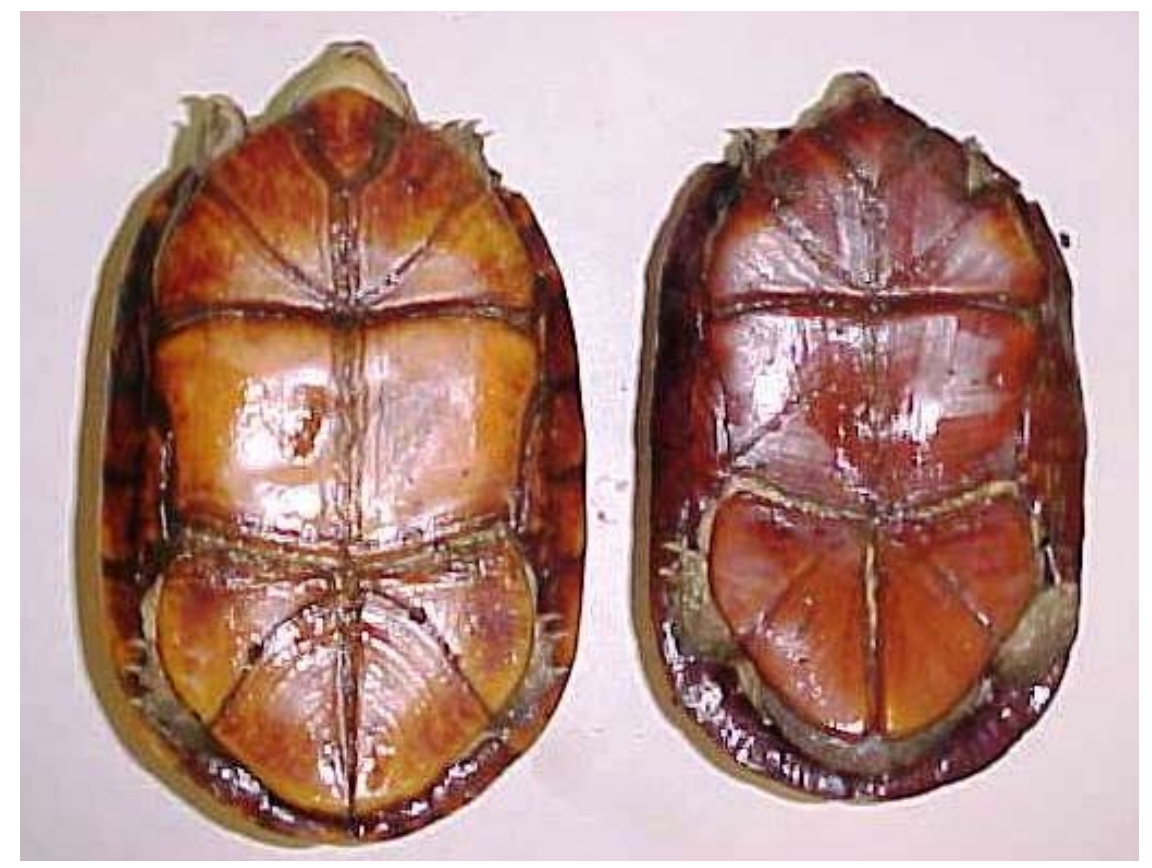

Figure 2. Adult female (left) and male (right) K. scorpioides albogulare from San Andrés Island, Colombia. Photo by G. Forero-Medina.

can be phenotypic intermediates between albogulare and cruentatum along the Pacific Coast in southern Guatemala and El Salvador. Apparently, there has been confusion regarding the identification of some individuals from Honduras, classified as K. s. cruentatum (Red-cheeked Mud Turtle) because individuals of $K$. s. albogulare can also have red markings on their heads (Iverson 2010).

Description. - The carapace is variable in color, from light brown to olive or dark olive, it has three keels that are less evident in older individuals, and a relatively high shell (carapace height $41 \%$ of carapace length [CL] in males and $46 \%$ in females) compared to the relatively flatter $K$. s. scorpioides (35\% and $38 \%$ of CL) and K. s.abaxillare (38\% and $39 \%$ of CL) (Berry and Iverson 2001). The plastron has two kinetic hinges, with lobes generally completely closing the ventral openings of the shell. Inguinal and axillary scutes are present and usually in contact (86\% of individuals) (Berry and Iverson 2001).

The head has yellow, cream pink, or orange dots or reticulations on a brown or gray background (Berry and Iverson 2001), with a yellow lower jaw and chin (Ernst and Barbour 1989). Its subspecific name is derived from the prefix albo, from the Latin albus, meaning white, and the Latin gulares, meaning "of the throat" (Berry and Iverson 2001).

Record size known for the subspecies is $157.7 \mathrm{~mm} \mathrm{CL}$ for a male (Forero-Medina et al. 2007) and $153.0 \mathrm{~mm} \mathrm{CL}$ for a female (Castaño-Mora 1992), both from San Andres Island, Colombia. Males are recognized by their longer and thicker tails and larger terminal spines (Berry and Iverson 2001).

There appears to be geographic variation in size for this taxon. The mean CL for individuals from Honduras examined by Iverson (2010) was $135.6 \pm 20.2 \mathrm{~mm}$ (males) and $125.8 \pm 7.8 \mathrm{~mm}$ (females); for individuals from Costa Rica, mean CL was $149.9 \pm 19.8 \mathrm{~mm}$ (males) and 141.6 \pm
$14.7 \mathrm{~mm}$ (females) (Iverson 2010). Male to female ratio in a population studied in Guanacaste, Costa Rica, was 1:2.5 (Acuña-Mesén 1990), while in San Andres Island the sex ratio was ca. 1:2 males to females (Forero-Medina et al. 2007). Acuña-Mesén and Márquez-B. (1993) studied the sexual dimorphism in a population in Palo Verde, Costa Rica, and found that females had a significantly higher mean weight and carapace width than males, while there was no significant difference in carapace length.

Distribution. - Kinosternon s. albogulare occurs from western Honduras and El Salvador, through Nicaragua, Costa Rica, and western Panama, as well as the Colombian island of San Andrés in the Caribbean (Ernst and Barbour 1989). It is not known when the species arrived on this island from the mainland. Although Dunn and Saxe (1950) suggested it might have arrived recently because of no recognizable differences with mainland populations,

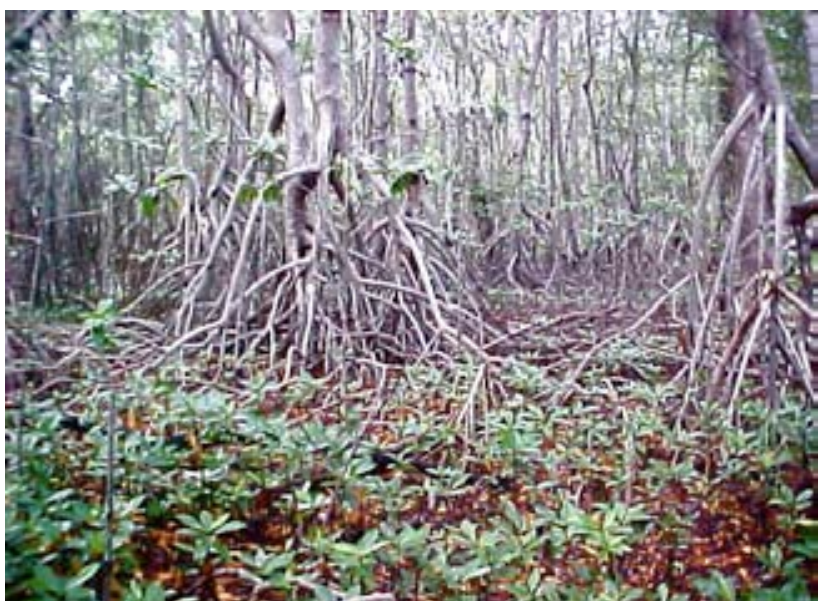

Figure 3. Mangrove swamp habitat of $K$. scorpioides albogulare on San Andrés Island, Colombia. Photo by G. Forero-Medina. 


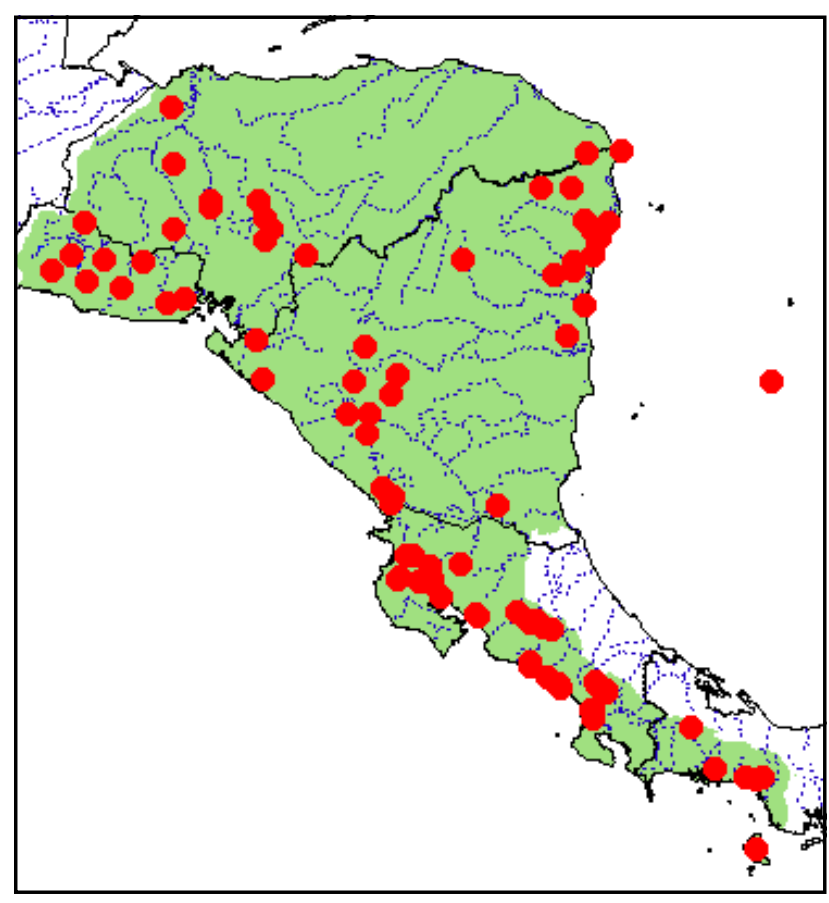

Figure 4. Distribution of Kinosternon scorpioides albogulare in Central America from Honduras and El Salvador through Nicaragua and Costa Rica to western Panama. The dot in the Caribbean Sea to the east of Nicaragua is the Colombian island of San Andrés. Red dots $=$ museum and literature occurrence records of native populations based on Iverson (1992), plus more recent and authors' data; green shading $=$ projected native distribution based on GIS-defined hydrologic unit compartments (HUCs) constructed around verified localities and then adding HUCs that connect known point localities in the same watershed or physiographic region, and similar habitats and elevations as verified HUCs (Buhlmann et al. 2009), and adjusted based on authors' data.

the island has been visited since the 1600s by Indians and traders. Genetic studies are needed to determine if the San Andrés population may be evolutionarily distinct.

Habitat and Ecology. - This taxon can be found in water bodies such as: 1) small or large freshwater ponds with varying degree of vegetation cover and macrophytes; 2) slow running streams; 3) swamps, and 4) floodable mangrove forests that are not permanently connected to the sea. Although it can tolerate saline environments, apparently very high salinity levels can limit its distribution (Forero-Medina et al. 2007). In Costa Rica it is not found above $1425 \mathrm{~m}$ of elevation (Savage 2002).

There is limited information regarding growth, sexual maturity, longevity, and reproduction for this taxon. Courtship and mating take place twice a year in Costa Rica, during January and July (Acuña- Mesén 1998), and eggs are laid in February and March and from August to November (Savage 2002). Another study indicates that nesting in Costa Rica occurs from August to February (Castillo-Centeno 1986). Nesting season in Honduras occurs around January (Iverson 2010), or from October to March, as has been reported for captive animals (Schilde 2001). Nesting in the San Andrés island population probably occurs during the dry season from February to May, when water levels in mangrove forests are low, as noted by local people (Forero-Medina, unpubl. data).
On this island, one egg was recorded by Dunn and Saxe (1950) measuring $31 \times 18 \mathrm{~mm}$. Two nests were recorded on San Andrés by Forero-Medina (unpubl. data) containing one and two eggs, respectively (mean size $=31.5 \pm 2.51 \times 14.9$ $\pm 2.97 \mathrm{~mm}$ ). Other mean egg sizes reported are: $32.8 \times 19.6$ $\mathrm{mm}$ in Costa Rica (Castillo-Centeno 1986; Acuña-Mesén 1998) and 39.6 x $15.0 \mathrm{~mm}$ in Honduras (Iverson 2010). Clutch size may vary from 1 to 6 eggs, but is commonly around 2 to 5 (Castillo-Centeno 1986; Acuña- Mesén 1998; Schilde 2001; Iverson 2010). In captivity in Colombia, two eggs per clutch have been reported, measuring $30 \times 17 \mathrm{~mm}$ to $35 \times 19 \mathrm{~mm}$, with an incubation period of 111 to 194 days (Castaño-Mora 1992).

Adult individuals from the Central American populations can be preyed upon by coyotes (Canis latrans) and large cats; eggs are heavily depredated by the coyote, and hatchlings and juveniles are eaten by coyotes, cats, raptors, and vultures (Savage 2002). There are no studies on predation on San Andrés Island, but potential predators include the introduced cayman, Caiman crocodilus, and the introduced egg-eating lizard, Tupinambis teguixin, which is very abundant in areas where turtles nest. Consumption of turtles by humans on the island is rare. Published reports of human consumption in Central America are scarce but there is evidence that indigenous people in the Maya region of Copan, in western Honduras, consume several species from the local herpetofauna, including $K$. s. albogulare (Marineros 2007).

This taxon exhibits both diurnal and nocturnal behavior, being more active at night. It is omnivorous and occasionally a scavenger. Recorded items in its diet include fruits, terrestrial and aquatic invertebrates (mainly molluscs and arthropods), and dipteran larvae, which is a common prey (Forero-Medina and Castaño 2006). The taxon is host to at least four species of nematode parasites, as has been reported for the continental populations of Costa Rica (Bursey and Brooks 2011).

Terrestrial movements are common; Teska (1976) reported observations of individuals as far as $500 \mathrm{~m}$ away from a marsh in the surrounding pastures and forests, and substantial movements (up to $175 \mathrm{~m}$ ) by several individuals in Guanacaste Province, Costa Rica. Data from a study using thread trailers showed that the mean travelled distance for a two day period was $68.27 \mathrm{~m}(\mathrm{n}=32, s=78.03)$ with no significant difference between males and females; and the maximum travelled distance was $380 \mathrm{~m}$ recorded for a male (Forero-Medina, unpubl. data). In this same study, mean net displacement for the two day period was $34.72 \mathrm{~m}$ ( $\mathrm{n}=36, s=51.59)$ with a maximum of $300 \mathrm{~m}$ for a male (Forero-Medina, unpubl. data).

Population Status. - The only population for which information on abundance is available is the one on San Andrés Island. In 1988 Castaño-Mora found only one pair of turtles in the largest pond and dense populations in the mangrove forests, suggesting that it might have abandoned freshwater ponds because of the introduction of Caiman crocodilus (Castaño-Mora 1992). However, sampling was 
not systematic and she did not give any estimation of population size or density. In 2002 the total population of the island was estimated to be 4343 individuals (3569-5800, $95 \%$ confidence limits), with densities varying from 77 to 254 turtles/ha (Forero-Medina et al. 2007). Further surveys are required to determine population trends.

Threats to Survival. - Human use for consumption or medicinal purposes occurs across its distribution, but is very rare and does not seem to represent a threat to any population. There is no massive commercial exploitation or trade of this subspecies, although individuals can be bought through the internet, apparently coming from raised stocks derived from populations in Honduras. It is likely that habitat loss is affecting the subspecies in some parts of its distribution, in western Panama, Nicaragua, and Honduras. In Honduras, no members of the herpetofauna are free from human impact and it has been suggested that the entire herpetofauna might be threatened, based on current and projected human population growth (Wilson and McCranie 2003). In Costa Rica, a study conducted in Palo Verde showed that fire killed 140 turtles in just three days and was responsible for $85.4 \%$ of the mortality during one year (Acuña-Mesén 1990). This study suggested that fire could have a strong effect on the structure of the population; most of the individuals that died were juveniles or females (Acuña-Mesén 1990). As fire is a common phenomenon along the tropical dry forests in Central and South America, it may be affecting other populations in the range. On San Andrés Island, contamination of some mangrove forests can be altering the habitat quality for the species, and the invasive Tupinambis teguixin, an introduced predator and egg specialist, represents the most serious threat to the population (Forero-Medina et al. 2007).

Conservation Measures Taken. - Neither this subspecies nor the species $K$. scorpioides are presently listed under the CITES Appendices or on the IUCN Red List, with the species considered Least Concern when evaluated by the IUCN Tortoise and Freshwater Turtle Specialist Group in 1996 and in 2010 (Turtle Taxonomy Working Group 2010). At the Colombian national level, it is considered regionally Vulnerable according to criterion D2 (Castaño-Mora and Forero-Medina 2000).

At least a few populations occur in some types of protected areas; it has been recorded in the Biosphere Reserve Seaflower, Colombia, and Bosawas, Nicaragua (Köhler 1999). In Central America some protected areas overlap its distribution range, although there are no confirmed records for the subspecies in all of these areas. In 2004, an Environmental Education Project for the conservation of the subspecies and its habitats was conducted on San Andrés Island, focusing on children living near mangrove forests, who successfully spread knowledge and awareness for the species in other schools and throughout the island (ForeroMedina and Mahecha 2006).

Conservation Measures Proposed. - Listing the taxon as threatened under the IUCN Red List is not recommended at this time, as $K . s$. albogulare is widely distributed and not apparently under threat from exploitation or significant habitat loss. Additionally, it occurs in some protected areas and appears to be locally abundant. However, there is a need for population studies throughout its range, which would lead to more accurate estimations of trends and conservation requirements at a local scale.

Current Research. - Very little research has focused on this subspecies, with some populations being considered only to the specific level. Future research on the reproduction and population ecology of the taxon is needed throughout its range in order to determine local population trends.

Acknowledgments. - We thank John B. Iverson for sharing unpublished observations.

\section{LITERATURE CITED}

AcuñA-MesÉn,R.A. 1998. Las Tortugas continentals de Costa Rica. 2nd Ed. San Jose: University of Costa Rica.

AcuÑA-MEsÉn,R.A.1990.Theimpact of fire and drought on the population structure of Kinosternon scorpioides (Testudines: Kinosternidae) in Palo Verde, Guanacaste, Costa Rica. Brenesia 33:85-97.

Acuña-Mesén, R.A. and Márquez-B.,C. 1993. Sexual dimorphism of Kinosternon scorpioides (Testudines: Kinosternidae) in Palo Verde, Costa Rica. Revista de Biologia Tropical 41:261-265.

BERRY, J.F. 1978. Variation and systematics in the Kinosternon scorpioides and K. leucostomum complexes (Reptilia: Testudines: Kinosternidae) of Mexico and Central America. Ph.D. Dissertation, University of Utah, Salt Lake City, Utah.

BERRY, J.F. AND IVERSON, J.B. 2001. Kinosternon scorpioides. Catalogue of American Amphibians and Reptiles 725:1-11.

BERRY, J.F. AND IVERSON, J.B. 2011. Kinosternon scorpioides (Linnaeus 1766) - Scorpion Mud Turtle.In:Rhodin,A.G.J.,Pritchard, P.C.H., van Dijk, P.P., Saumure, R.A., Buhlmann, K.A., Iverson, J.B., and Mittermeier, R.A. (Eds.). Conservation Biology of Freshwater Turtles and Tortoises: A Compilation Project of the IUCN/SSC Tortoise and Freshwater Turtle Specialist Group. Chelonian Research Monographs No. 5, pp. 063.1-063.15.

Buhlmann, K.A., Akre, T.S.B., Iverson, J.B., Karapatakis, D., Mittermeier, R.A., Georges,A., Rhodin,A.G.J., van DiJK, P.P., AND GibBons, J.W. 2009. A global analysis of tortoise and freshwater turtle distributions with identification of priority conservation areas. Chelonian Conservation and Biology 8(2):116-149.

BuRSEY, C.R. AND BROOKS, D.R. 2011. Nematode parasites of five species of turtles from the Area de Conservación Guanacaste, Costa Rica, with description of a new species of Falcaustra. Comparative Parasitology 78:107-119.

Cabrera, M.R. and Colantonio, S.E. 1997. Taxonomic revision of the South American subspecies of the turtle Kinosternon scorpioides. Journal of Herpetology 31:507-513.

Castaño-Mora, O.V. 1992. Informe final del proyecto "Las tortugas de Colombia”, Fase II. Bogotá: Universidad Nacional Colciencias.

Castillo-Centeno, O. 1986. Factores ecológicos y de mercado de la reproducción de Rhinoclemmys pulcherrima y Kinosternon scorpioides (Testudines: Emydidae y Kinosternidae) en Costa Rica. Thesis, Ciudad Universitaria “Rodrigo Facio," San Jose, Costa Rica.

DuMERIL, A.M.C. AND BocourT, M.-F. 1870. Observations sur les reptiles et les batraciens de la région central de l'Amerique, etudes sur les reptiles. Mission scientifique au Mexique et dans 1'Amerique Centrale (3rd part):1-32. 
DunN,E.R. ANDSAXE,L.H.1950. Results of the Catherwood-Chaplin West Indies Expedition, 1948. Part V. Amphibians and reptiles of San Andrés and Providencia. Proceedings of the Academy of Natural Sciences of Philadelphia 102:141-165.

ERnST, C.H. AND B ARBour, R.W. 1989. Turtles of the World. Washington, DC: Smithsonian Institution Press, 313 pp.

Forero-Medina, G., Castaño-Mora, O.V., and Montenegro, O. 2007. Abundance, population structure and conservation of Kinosternon scorpioides albogulare on the Caribbean Island of San Andres, Colombia. Chelonian Conservation and Biology 6:163-169.

Forero-Medina, G. and Castaño-Mora, O. 2006. Kinosternon scorpioides albogulare. Feeding behavior and diet.Herpetological Review 37:458.

Forero-Medina, G. And Mahecha, A.M. 2006. Una estrategia de conservación en San Andrés Isla: proyectos escolares y valores en la educación ambiental. Gestión y Ambiente 9:115-127.

IvERSON, J.B. 1992. A Revised Checklist with Distribution Maps of the Turtles of the World. Richmond, Indiana: Privately printed, 393 pp.

IVERSON, J.B. 2010. Reproduction in the red-cheeked mud turtle (Kinosternon scorpioides cruentatum) in southeastern Mexico and Belize, with comparisons across the species range. Chelonian Conservation and Biology 9(2):250-261.

KöHLER, G. 1999. The Amphibians and Reptiles of Nicaragua: A Distributional Checklist with Keys. Courier Forschungsinstitut Senckenberg 213:1-121.

MARINEROS, L.E. 2007. El consumo de anfibios y reptiles entre los Maya Chortí de Copan. Yaxkin 23:182-193.

SAvage, J.M. 2002. The Amphibians and Reptiles of Costa Rica: A Herpetofauna between Two Continents, between Two Seas. Chicago: The University of Chicago Press.
SCHILDE, M. 2001. Schlammschildkröten: Kinosternon, Sternotherus, Claudius, und Staurotypus. Münster, Germany: Natur und Tier-Verlag, $133 \mathrm{pp}$.

Teska, W.R. 1976. Terrestrial movements of the mud turtle Kinosternons scorpioides in Costa Rica. Copeia 1976:579-580.

Turtle TAXonomy Working Group [Rhodin, A.G.J., van DiJK, P.P., IVERSON,J.B., AND SHAFFER,H.B.]. 2010.Turtles of the world, 2010 update: annotated checklist of taxonomy, synonymy, distribution, and conservation status.In: Rhodin,A.G.J.,Pritchard,P.C.H., van Dijk, P.P., Saumure, R.A., Buhlmann, K.A., Iverson, J.B., and Mittermeier, R.A. (Eds.). Conservation Biology of Freshwater Turtles and Tortoises: A Compilation Project of the IUCN/SSC Tortoise and Freshwater Turtle Specialist Group. Chelonian Research Monographs No. 5, pp. 000.85-000.164.

WiLson, L.D. AND McCRANIE, J.R. 2003. The conservation status of the herpetofauna of Honduras. Amphibian and Reptile Conservation 3:6-33.

\section{Citation Format for this Account:}

Forero-Medina, G. and Castaño-Mora, O.V. 2011. Kinosternon scorpioides albogulare (Duméril and Bocourt 1870) - WhiteThroated Mud Turtle, Swanka Turtle. In: Rhodin, A.G.J., Pritchard, P.C.H., van Dijk, P.P., Saumure, R.A., Buhlmann, K.A., Iverson, J.B., and Mittermeier, R.A. (Eds.). Conservation Biology of Freshwater Turtles and Tortoises: A Compilation Project of the IUCN/SSC Tortoise and Freshwater Turtle Specialist Group. Chelonian Research Monographs No. 5, pp. 064.1-064.5,doi:10.3854/crm.5.064.albogulare.v1.2011,http:// www.iucn-tftsg.org/cbftt/. 